\title{
MEF2D Gene
}

National Cancer Institute

\section{Source}

National Cancer Institute. MEF2D Gene. NCI Thesaurus. Code C92164.

This gene plays a role in muscle and neuronal development. 